sciendo Порівняльна професійна педагогіка 8(3)/2018 Comparative Professional Pedagogy 8(3)/2018

DOI: $10.2478 /$ rpp-2018-0039

Lecturer, VITALII HONCHARUK

Pavlo Tychyna State Pedagogical University in Uman Address: 2 Sadova St, Uman, 20300, Ukraine E-mail: goncharuk424@ukr.net

PhD in Biology, Associate Professor, NATALIIA HNATIUK

Pavlo Tychyna State Pedagogical University in Uman Address: 2 Sadova St, Uman, 20300, Ukraine

E-mail: nat-gnatiuk@ukr.net

PhD in Pedagogy, Senior Lecturer, OLENA ZADOROZHNA

Pavlo Tychyna State Pedagogical University in Uman Address: 2 Sadova St, Uman, 20300, Ukraine E-mail: zadoroschnao@ukr.net

\title{
ECOLOGICAL TRAINING OF FUTURE NATURAL SCIENCES TEACHERS IN HIGHER EDUCATION INSTITUTIONS ABROAD
}

\begin{abstract}
The problem on ecological training of future natural sciences teachers in Ukrainian and foreign higher education institutions was comparatively analyzed. Novel approaches to ecological education based on the systemic and personality-oriented learning were considered. The forms and methods used to promote ecological education of the individual in Ukraine and abroad were outlined. The studies of individual scholars on the foreign experience in creating an ecologically rational research and educational environment in the UK, Germany, the USA, Moldova and other countries were justified. It was indicated that West European countries created relevant conditions for transforming a model of humanistic education into an eco-humanistic one since it should be considered as a wide-scale educational achievement. It was found that the education process in British universities was targeted at ecological education organization and focused on its practical aspect, namely ecological environment preservation. In the country, there is a national system of ecological education aimed at eliminating the negative effects of the industrialization and the progress of science and technology. The education process in this country employs the forms and methods, which promote ecological education of the individual such as observations, discussions, laboratory work, fieldwork, presentations, etc. In some German universities, considerable attention is paid to regulating the negative changes in nature and mastering the skills for their prevention and elimination. Although there is no a federal standard for ecological education in the USA, it is mandatory in many states and considered not as an abstract phenomenon, but a concrete regional activity. In the country, they also conduct numerous researches on regional ecological problems and actively search for the ways to solve them. It was concluded that the foreign research and educational environment aims to discover the ways to optimize the knowledge of the relationship between man and nature and protect and preserve the environment.

Keywords: ecological training, future natural sciences teachers, ecologically rational research and educational environment in higher education institutions, ecological culture of
\end{abstract}


sciendo Порівняльна професійна педагогіка 8(3)/2018

Comparative Professional Pedagogy 8(3)/2018

personality, ecological education of students and pupils, foreign experience of environmental management, ecology-oriented research activities, international cooperation in the environmental protection sector.

\section{INTRODUCTION}

The strategy for solving ecological problems is primarily based on the awareness of the relationship between man and nature. In Ukraine, ecological education of young people has become one of the priorities in the development of society. Environmental protection is one of the strategic objectives aimed at strengthening European integration. The priority of ideals and values within the human-nature interaction is an important condition for achieving sustainable development of society at the international and national levels.

The relevance of ecological problems is compounded by Ukraine's entry into the European and global space, which requires that the teacher should significantly expand his/her functions. Thus, they should be able to master and further employ new teaching technologies, transform the educational paradigm into an effective pedagogical system through replacing reproductive teaching with creative one, etc.

Nowadays, economically developed countries demonstrate a powerful experience in providing ecological training in higher education institutions. Modern lifestyle causes the need to "ecologize" thinking and, in particular human activity. Modern higher education institutions should provide young people with profound professional knowledge and, most importantly, cultivate their ecological culture, develop their ecological views implying a careful attitude to the environment. Therefore, it is imperative to prepare relevant specialists for ecological education implementation.

\section{THE AIM OF THE STUDY}

This study aims to comparatively analyze Ukrainian and foreign experience of providing natural sciences students with ecological education in higher education institutions and to outline the educational forms and methods, which contribute to ecological education of personality, and discover the main ways to solve ecological problems, protect and preserve the environment.

\section{THEORETICAL FRAMEWORK AND RESEARCH METHODS}

The research and educational environment in higher education institutions is an important information platform for the students who intend to teach and educate a new generation that should be able to solve global problems. Therefore, the main objectives in the Ukrainian strategy for education and science development are the following: 1) to study foreign experience of providing future natural sciences teachers with ecological education and 2) to introduce the most positive aspects of this experience into higher education institutions in Ukraine.

Novel approaches to ecological student education based on the systematic and personality-oriented learning, theoretically structured principles, conditions, modes of learning, experience, theory and practice of ecological training abroad are disclosed in the researches by the following scholars: N. Bidyuk, H. Marchenko, Ya. Poliakova, I. Zadorozhna - the UK; D. Kvasnychkova - the Czech Republic; O. Romanova - Belarus; I. Rudkovska Germany), D. Tsykhi - Poland. The individual aspects of ecological teacher training in the UK were studied by Yu. Alforova, H. Andrieieva, N. Avshenuyk, Yu. Kishchenko, O. Leontieva, O. Matviienko, L. Pukhovska.

Many scholars (N. Morze, M. Krylovets, S. Semenets, V. Sharko, O. Zadorozhnaya et al.) studied ecological training of future subject teachers in Ukraine. In particular, 
T. Bondarenko, N. Mishchuk, I. Moroz, V. Shuldyk, A. Stepaniuk and O. Tsurul devoted their researches to individual aspects in methodological training of biology teachers. N. Hnatiuk (2014) considered the features of implementing research activities in the context of modern education.

The current research relies on the main ideas of the following Ukrainian and foreign scholars. Thus, O. Bondar (2006) studies world trends in ecological education, while M. Hadzhyiev (2007) describes bachelor's courses on natural sciences in pedagogical universities. S. Hilmiiarova (2002) compares the continuity of ecological education for future teachers in Russia and the USA. O. Zadorozhna (2018) analyzes the process of developing worlview in pedagogical universities students by means of nature protection. Ye. Klimut (2002) justifies socioecological training of teachers in Germany, whereas T. Kuchai (2009) characterizes the British system of developing future teachers' readiness to provide ecological training. I. Sichko (2011) clarifies the features of ecological education in educational institutions abroad. T. Chuan (2003) contextualizes attitudes and strategies of US educators towards ecological education development. R. Floden \& M. Meniketti (2005) discuss the influence of research activities on the research potential of future natural sciences teachers. P. Tarhon (2004) explores general didactic principles in ecological training of biology teachers.

The following research methods were used to achieve the aim of the study: theoretical methods (analysis of psychopedagogical literature) justified the starting point of the research; interpretive and analytical methods serves as the basis for synthesis, analysis, systematization and generalization of Ukrainian and foreign sources; comparative historical analysis revealed trends in the development of higher education abroad and identified similar and distinctive features in the content of teacher training in Ukrainian and foreign higher education institutions.

\section{RESULTS}

To begin with, the British education system is internationally recognized and is well-known for its innovative teaching and learning technologies. Therefore, T. Kuchai's research (2009) is of great scientific interest for our study since the scholar explores the cultivation of teachers' pedagogical mastery under the conditions of teacher education development, as well as professional training of English language teachers in the UK and the ways to implement the innovative ideas of British experience in Ukraine.

According to T. Kuchai (2009), ecological training of natural sciences students in British higher education institutions is mainly aimed at developing their individual readiness to preserve and rationally use natural resources, nurture a harmonious relationship between man and nature and protect the environment. In the UK, they have established an original national system of ecological education aimed at eliminating the negative effects of the industrialization and the progress of science and technology. This important activity is based on universal values and national traditions of environmental protection and promotes ecological ideas within society, which can be evidenced by the national documents such $A$ Children's Environment and Health Strategy for the United Kingdom (2008); Freedom of Information Environmental Protection (The Environmental Information Regulations) (2004) etc. They highlight the need to increase attention to ecological education, as well as education of different categories of the population and identify the priority areas of their further development (Kuchai, 2009).

As shown by a thorough analysis on the British model of training future teachers to implement ecological education of pupils, it is aimed at involving different groups of the 
sciendo Порівняльна професійна педагогіка 8(3)/2018 Comparative Professional Pedagogy 8(3)/2018

population into environmental protection, which is a holistic pedagogical theory and practice with its inherent laws, principles and forms.

In the UK, teacher training involves attracting future teachers' attention to the need to "ecologize" the education process. In addition, British university curricula incorporate individual environment-oriented modules. Thus, natural sciences students of University of Roehampton study the following modules: Ecology, Forest Ecology, Environmental Physiology, Ecosystems, Human Rights (19\% of the total curriculum time). At the University of Leeds, natural sciences students master such modules as Ecology, Ecology Development, Environmental Science, Environmental Protection (21\% of the total curriculum time). The University of Glasgow offers the following modules: Ecology, Forest Ecology, Environmental Science, Molecular Ecology, Ecology and Environmental Protection, Environmental Analysis, Environmental Management (35\% of the total curriculum time) (Kuchai, 2009, pp. 170-172).

In the UK, the problem of rational environmental management and protection is efficiently solved provided that the continuity of ecological education (general secondary education - higher education - advanced training) is ensured. The education process in British universities is targeted at ecological education organization and focused on its practical aspect, namely ecological environment preservation since it employs the forms and methods, which promote ecological education of the individual, namely observations, discussions, laboratory work, fieldwork, presentations, etc. Some universities pay considerable attention to controlling the negative changes in nature and mastering the skills for their prevention and elimination. It must be noted that the scope of teacher professional development also includes ecological education with the aim to enhance ecological literacy of teachers.

Comparative analysis on the content characteristics of ecological education and methodologies of training future teachers for ecological education in the UK and Ukraine proves similar approaches to organizing the education process in both countries, namely the credit based modular curriculum, forms of the education process organization (lectures, seminars, practical classes, tutorials, discussions, methodical presentations, etc.). At the same time, there are some peculiar features in professional training of future teachers in the UK, namely practice-oriented ecological modules; a wide range of optional modules; considerable time for independent study; well-organized research activities on ecology and ecological education; application of teaching methods that contribute to developing critical thinking of future teachers.

Most West European countries and the USA establish the centres for ecological education. In the USA in particular, these centres are based in museums and libraries, some of them having the international status (Gilmiyarova, 2002, p. 116). O. Bondar and T. Saienko (2006) state that although there is no a federal standard for ecological education in the USA, it is mandatory in many states. In addition, ecological education is considered not as an abstract phenomenon, but a concrete regional activity. Specific attention is paid to research activities, as well as studies on ecological problems in the area of residence.

I. Sichko (2011) indicates that at the University of Michigan (USA) they optimally combine theoretical (developing theoretical knowledge) and pratical training (being involved in teacher placements) within degree courses on environmental protection. Due to teacher placements, teachers-to-be learn how to solve specific ecological problems and simultaneously impart their knowledge on their pupils. In addition, much attention is focused on practical methods and forms of learning, namely practical classes, fieldwork, waste management measures, landscaping, animal rescue operations. In the USA, ecological education aims to discover the ways to optimize the knowledge of the relationship between man and nature and protect and preserve the environment. 
In Europe during the second half of the 20th century, the problems of environmental protection were rather fragmentarily studied. Despite the fact that the curriculum normally included the module on Environmental Protection, the latter mainly considered professional safety. The situation improved after the introduction of postgraduate education, which presupposed multidisciplinary approach to environmental science (Bondar, 2006). Nowadays, West European countries regularly create relevant conditions for transforming a model of humanistic education into an eco-humanistic one since it should be considered as a widescale educational achievement.

Ye. Klimut (2002) states that German scholars hold different views on achieving the aim of ecological education. The followers of traditional pedagogy (Umwelterziehung) prove that ecological education should be provided within one subject or be included in the content of all subjects. There is also an alternative approach or eco-pedagogy (Oekopaedagogik), whose supporters oppose instrumental thinking and promote comprehension of environmental perceptions. They approve socioecological training of teachers, whose essence should be seen in the development of ecological culture, that is, an attitude to the environment.

M. Gadzhiev (2007) indicates that the international cooperation on ecological education in European universities includes the following areas: an exchange of information about the research findings on the ecological conditions of the environment; joint research and methodological developments in the field of educational technologies that contribute to developing ecological culture of young people, as well as initiation and implementation of joint ecological educational and research projects and programmes; an organization of the international ecological tourism and fieldwork; a joint organization of international forums, conferences, seminars, participation in the activities of international funds; scientific internships in the field of ecological education (pp. 65-66).

Special attention should be paid to the organization of ecological education in I. Shamiakin State Pedagogical University in Mazyr (Belarus). The Biology Faculty of the University offers the course on Biology and Environment Protection. Within the course, students are taught the following modules: Environmental Management (Years 3 and 4), Human Ecology (Year 3), Economics and Environmental Management (Years 3 and 4), Teaching Methodology of Environmental Protection (Years 3 and 4), Ecology, Radioecology and Energy Preservation (Year 4), Ecology of Modern Production and Environmental Monitoring (Year 4). In addition, the curriculum includes practical training in the field of environmental management and environmental protection and ecology (Mozyrskyi gosudarstvennyi pedagogicheskiy universitet imeni Y. P. Shamiakina, 2013).

The Moldova State University, in addition to the basic module on Didactica biologiei (Biology Didactics) (2004), offers methodological modules such as Educational Technologies, Biological Experiment Methods etc. During methodological training, they mostly use interactive teaching methods, computer technologies, the project method, portfolios, etc.

The above-mentioned achievements of foreign countries in the field of ecological education should be studied in detail, creatively reconsidered and coordinated with the national system of education.

\section{CONCLUSIONS}

The foreign education systems are worldwide recognized for their high-ranking universities and innovative technologies of teaching and learning.

Indeed, the UK's state policy focuses on ecological priorities since the country heads the Commonwealth of Nations, uniting more than a billion people on the planet and 
sciendo Порівняльна професійна педагогіка 8(3)/2018

Comparative Professional Pedagogy 8(3)/2018

therefore contributes to creating an international system of ecological education and its implementing into educational practice. A thorough analysis of methodological framework for training future teachers for ecological education in the country allowed discovering the ways to creatively impelement its innovative ideas into the system of ecological education in Ukraine.

The research findings prove that in the countries of near and far abroad (the USA, Germany, Moldova, Belarus), they pay considerable attention to ecological training of natural sciences students. In addition, they regularly update the content of ecological training in accordance with current educational trends, introduce specialized ecological modules, promote innovative teaching technologies of teaching and learning, as well as develop the latest educational and methodological support, in particular, for distance learning. Ukrainian educators, theoriticians and practitioners, as well as relevant specialists should thoroughly study their achievements and implement them into ecological education of natural sciences students.

Further studies should be focused on better understanding of the foreign experience in organizing methodical training of natural sciences teachers and developing their ecological culture so that its positive aspects may be implemented into the national system of higher education.

\section{REFERENCES}

1. Bondar, O. I. (2006). Svitovi tendentsii v ekolohichnii osviti. Ekolohichnyi visnyk, 4, 18-22.

2. Chuan, H. C. (2003). Teaching evolution: attitudes and strategies of educators in Utah. American Biology Teacher, 65 (9), 669-674.

3. Floden, R. E., \& Meniketti, M. M. (2005). Research on the effects of coursework in the arts and sciences and in the foundations of education. Studying Teacher Education: Report of the AERA Panel on Research and Teacher Education, 261-308.

4. Freedom of Information Environmental Protection. No. 3391. (2004).

5. Gadzhiev, M. M. (2007). Sistema ekologicheskoi podgotovki bakalavrov estestvennonauchnogo obrazovania v pedagogicheskom universitete. (Diss. d-ra ped. nauk). Rossiiyskiy gosudarstvennyi pedagogiicheskiy universitet imeni A. I. Gertsena, Sankt-Peterburg.

6. Gilmiyarova, S. G. (2002). Nepreryvnoe ekologicheskoe obrazovanie budushchikh uchiteley v Rossii y SSHA. (Dys. d-ra ped. nauk). Bashkirskiy gosudarstvennyi pedagogicheskiy universitet, Ufa.

7. Health Protection Agency. (2008). A Children's Environment and Health Strategy for the United Kingdom. Retrieved from http://sanidadambiental.com/wp-content/uploads/ 2009/06/1207121679366.pdf.

8. Hnatiuk, N. (2014). Osoblyvosti vykorystannia navchalno-doslidnoi dilianky v konteksti suchasnoi osvity. Zbirnyk naukovykh prats Umanskoho derzhavnoho pedahohichnoho universytetu imeni Pavla Tychyny, 2, 72-78.

9. Klimut, E. N. (2002). Aktualnost sotsyalno-ekologicheskoy podgotovki uchiteley $v$ Germanii, Materialy VIII Mezhdunarodnoy konferentsii po ekologicheskomu obrazovaniu "Ekologicheskoe obrazovanie: na porohe" RYO + 10". Tver: HUPTO TOT.

10. Kuchai, T. P. (2009). Pidhotovka maibutnikh uchyteliv $v$ universytetakh Velykoi Brytanii do ekolohichnoho vykhovannia uchniv. (Dys. kand. ped. nauk). Cherkaskyi natsionalnyi universytet imeni Bohdana Khmelnytskoho, Cherkasy. 
sciendo Порівняльна професійна педагогіка 8(3)/2018 Comparative Professional Pedagogy 8(3)/2018

11. Mozyrskyi gosudarstvennyi pedagogicheskiy universitet imeni Y. P. Shamiakina. (2013). Rabochiy uchebnyi plan. Dnevnaia forma polucheniya vysshego obrazovaniya. Vzyato s http://biology.mspu.by/.

12. Sichko, I. (2011). Osoblyvosti ekolohichnoi osvity u vyshchykh navchalnykh zakladakh zarubizhnykh krain. Porivnialno-pedahohichni studii, 1 (14). Vziato z http://pps. udpu.edu.ua/article/view/18554/16298.

13. Tarhon, P. (2004). Didactica generală a biologiei. Chişinău: Reclama.

14. Zadorozhna, O. M. (2018). Formuvannia svitohliadnykh perekonan u studentiv pedahohichnykh universytetiv zasobamy pryrodookhoronnoi diialnosti. (Dys. kand. ped. nauk). Umanskyi derzhavnyi pedahohichnyi universytet imeni Pavla Tychyny, Uman. 